\title{
STUDI PENGEMBANGAN KELEMBAGAAN BERDASARKAN KULTUR MASYARAKAT LOKAL PADA KELOMPOK NELAYAN ${ }^{1}$
}

\author{
Ermayant $^{2}$
}

\begin{abstract}
This article is the result of research on the social institutions that can provide a positive force for the fishermen in their daily lives. Social institutions fishery in this case is able to provide answers to social problems such as poverty. Strengthening social group of fishermen through social institutions is an urgent need and absolutely necessary by fishermen, so they can compete in a conducting fisheries and to improve the welfare of her life.
\end{abstract}

The results showed that traditional institutions are still living in Nagari Tiku Selatan is a 'kelompok sosial pengajian', 'arisan and 'yasinan', still running well. Participation of households on social groups is also very good. Almost all of the mothers involved in the routine activities of the group. 'Pengajian' and 'yasinan' conducted each week in rotation from house to house. While gathering held every two weeks. Social strategy is done by utilizing the social ties that exist in rural areas in the form of local welfare agencies, production relationship to kinship-based social networking or friendship.

Keywords: Social Institutions, Fishermen, Fisheries

\section{A. Pendahuluan}

$\mathrm{P}$ ropinsi Sumatera Barat merupakan salah satu propinsi yang berada di pesisir Barat pulau Sumatera yang memiliki potensi penangkapan dan pengelolaan ikan di laut yang sangat besar. Hal ini didukung oleh pantai sepanjang 375 $\mathrm{km}$, yang dimulai dari Kabupaten Pasaman Barat di utara sampai Kabupaten Pesisir Selatan di selatan, serta $2.420 \mathrm{~km}$ jika termasuk pantai di Kepulauan Mentawai (Zamzami, 2010;113)

Salah satu daerah yang menjadi sentral nelayan dan usaha kelautan di Sumatra Barat selain daripada Kabupaten Pesisir Selatan, Kota Padang, Kabupaten Padang Pariaman dan Kabupaten Pasaman Barat adalah Kabupaten Agam, tepatnya di Kecamatan Tanjung Mutiara,. Masyarakat nelayan di daerah ini terpusat di nagari Tiku Selatan dan nagari Tiku $V$ Jorong. Kedua nagari tersebut merupakan kawasan pemukiman nelayan yang selalu mengalami pasang surut dalam bidang perekonomian dan tidak berdaya dalam mengikuti perkembangan teknologi penangkapan ikan. Hal ini mengakibatkan kehidupan nelayan sering dibelit kemiskinan, rendahnya pendidikan dan pengetahuan, dan kurangnya informasi karena keterisolasian masyarakat setempat.

Berbagai kajian mengenai kehidupan nelayan umumnya menekankan pada kemiskinan dan ketidakpastian perekonomian, karena kesulitan hidup yang dihadapi nelayan dan keluarganya (Acheson, 1981, Emerson, 1980). Kehidupan nelayan dapat dikatakan tidak saja belum berkecukupan, melainkan juga masih terbelakang, termasuk dalam hal pendidikan. Keterbatasan sosial yang dialami nelayan memang tidak terwujud dalam bentuk keterasingan, karena secarafisik masyarakat nelayan tidak dapat dikatakan terisolasi atau terasing. Namun,

\footnotetext{
${ }^{1}$ Artikel ini merupakan hasil penelitian hibah dana fakultas ISIP tahun 2013

${ }^{2}$ Penulis adalah dosen tetap jurusan Antropologi FISIP Universitas Andalas, Padang
} 
lebih terwujud pada ketidakmampuan mereka dalam mengambil bagian dalam kegiatan ekonomi pasar secara menguntungkan, yang ditunjukkan oleh lemahnya mereka mengembangkan organisasi keluar lingkungan kerabat mereka atau komunitas lokal (Boedhisantoso, 1999; Zamzami, 2010:114).

Dalam rangka mengatasi masalah yang dihadapi nelayan tersebut, maka sejak tahun 2001-2008, pemerintah telah mencanangkan suatu program yang diupayakan dapat langsung menyentuh kepentingan masyarakat nelayan, terutama nelayan tradisional yang berorientasi kepada pertumbuhan ekonomi. Di samping bertujuan untuk meningkatkan kesejahteraan masyarakat nelayan, juga bertujuan untuk mendidik agar nelayan lebih mandiri dan mempunyai kemampuan untuk hidup lebih baik dalam memanfaatkan sumber daya yang ada secara optimal dan berkelanjutan. Melalui program pemerintah melalui program pemberdayaan ekonomi masyarakat pesisir $(\mathrm{PEMP})^{3}$, tetap memerhatikan sistem nilai dan kelembagaan yang tumbuh dan berkembang dalam masyarakat lokal, sehingga program yang ada tersebut diharapkan dapat meningkatkan partisipasi masyarakat dalam pengambilan keputusan dan pengawasan pengelolaan sumber daya laut dan daerah pesisir (Departemen Kelautan dan Perikanan, 2001: 6-7; Zamzami, 2010:114).

\footnotetext{
${ }^{3}$ Program PEMP yang dilaksanakan di propinsi Sumatera Barat sendiri dilaksanakan pada tahun 2001 di 4 Kabupaten/Kota, yaitu Pesisir Selatan, Pasaman, Padang Pariaman dan Kota Padang. Untuk pelaksanaan PEMP tahun 2001 di Kabupaten Pesisir Selatan dilaksanakan di 3 (tiga) nagari yang terdapat di Kecamatan Ranah Pesisir, yaitu kampung Nyiur Melambai, kampung Pasir Palangai dan kampung Pasir Harapan. Setiap lokasi yang dijadikan sasaran program PEMP dibentuk kelompok Masyarakat Pemanfaat (KMP) yang nantinya akan memperoleh bantuan dari program tersebut (Lebih lanjut baca Zamzami, Lucky (2011). Pemberdayaan Ekonomi Masyarakat Pesisir di Nagari Amping Perak, Sumatera Barat dalam Jurnal MIMBAR Unisba-Akreditasi B Dikti)
}

Selama proses pelaksanaan
program pemberdayaan masyaraka tersebut, masyarakat yang berbasis komunitas lokal telah mengembangkan kelembagaan dari aspek kelembagaan secara sosial dan ekonomi yang berisi nilainilai tradisional dan kearifan lokal sehingga setiap program pemerintah yang masuk ke wilayahnya dapat ditampung melalui kelembagaan yang telah terbentuk tersebut ${ }^{4}$. Keberadaan kelembagaan sosial ekonomi dalam masyarakat nelayan mampu mewujudkan rasa saling tolong menolong dan toleransi diantara kelompokkelompok nelayan yang setiap tahunnya terbentuk dengan sendirinya. Lembaga dalam suatu komunitas masyarakat pesisir terdiri dari organisasi pada tingkat nelayan serta kelembagaan masyarakat desa yang diartikan sebagai "norma lama" atau aturan-aturan sosial yang telah berkembang secara tradisional dan terbangun atas budaya lokal sebagai komponen dan pedoman pada beberapa jenis/tingkatan lembaga sosial yang saling berinteraksi dalam memenuhi kebutuhan pokok masyarakat untuk mempertahankan nilai. Norma lama yang dimaksud yaitu aturan-aturan sosial yang merupakan bagian dari lembaga sosial dan simbolisasi yang mengatur kepentingan

4 Program PEMP bertujuan untuk (1) meningkatkan partisipasi masyarakat dalam perencanaan, pelaksanaan, pengawasan dan pengembangan kegiatan ekonomi masyarakat; (2) memperkuat kelembagaan sosial ekonomi masyarakat dan kemitraan dalam mendukung pembangunan daerah; (3) memicu usaha ekonomi produktif di desa pesisir; (4) mendorong terlaksananya mekanisme manajemen pembangunan masyarakat yang partisipatif dan transparan; (5) meningkatkan kemampuan aparat dan masyarakat pesisir dalam mengelola pembangunan di wilayahnya; dan (6) mereduksi pengaruh kenaikan harga bahan bakar minyak melalui penciptaan dan peningkatan usaha ekonomi produktif secara berkesinambungan tersebut (Lebih lanjut baca Zamzami, Lucky (2011). Pemberdayaan Ekonomi Masyarakat Pesisir di Nagari Amping Perak, Sumatera Barat dalam Jurnal MIMBAR Unisba-Akreditas B Dikti) 
masyarakat di masa lalu (Sallatang, 1982; Arief, 1999).

Selain adanya program pemberdayaan yang dilaksanakan oleh pemerintah, salah satu sarana untuk memberikan perlindungan pada masyarakat nelayan adalah membekali mereka dengan pengetahuan akan arti penting hidup berkelompok Pada masyarakat nelayan, pola hidup berkelompok sebenarnya sudah lama dikenal, namun aktivitas mereka belum banyak yang mengarah pada pengangkatan sosial ekonomi mereka. Menyadari akan hal tersebut, pemerintah melaksanakan berbagai kegiatan yaitu pengelolaan yang berbasis masyarakat. Pengelolaan yang berbasis pada masyarakat oleh pemerintah sebenarnya sudah pernah dilakukan. Namun pengelolaan itu, lebih banyak berdimensi politik daripada sosial, ekonomi, dan budaya lokal dikarenakan sifat pengelolaannya bersifat top-down. Sebagai contoh; pembentukan LMD (BPD), LKMD, Karang Taruna, Dasa Wisma, Pos Yandu dan lainnya. Lembaga-lembaga ini sebagian kurang berfungsi dalam melaksanakan tugasnya, dan mereka tidak lebih hanya sekedar penghias nama di Kantor-kantor desa.

Lembaga lain yang ada di wilayah pesisir Sumatera Barat adalah lembaga sosial (tradisional) yang kehadirannya memang diperlukan oleh masyarakat. Sebagai contoh lembaga Arisan (julo-julo). Wirid Pengajian (Yassin), Sosial Kematian, gotong royong yang sifatnya bottom up. Secara subtansial, lembaga ini bertujuan untuk meningkatkan sosial ekonomi anggota dan memberikan rasa aman dan keselamatan dalam kehidupan bermasyarakat. Oleh karenanya lembaga ini secara konsisten melaksanakan aktivitasnya secara rutin. Hari yang diambil untuk melaksanakan aktivitasnya terutama pada hari Jum'at. Karena pada hari itu, mereka tidak melakukan aktivitas melaut, dan ada satu pandangan yang positif dari penetapan hari tersebut. Masyarakat "Melayu" mempunyai suatu keyakinan bahwa pada hari Jum'at, merupakan hari terbaik dari hari-hari lain, sehingga hari itu juga menjadi hari keramat.

Selama ini berbagai bentuk kelembagaan yang berjiwa ekonomi di setiap kelompok sosial nelayan yang banyak kita temukan di wilayah propinsi Sumatera Barat, khususnya Kabupaten Agam telah dikembangkan, namun pengembangannya terkesan sebagai alat kelengkapan proyek, belum sebagai wadah untuk pemberdayaan masyarakat secara hakiki. Akibatnya, eksistensi dan kinerjanya kurang mengembirakan, bahkan keberadaannya tidak berkesinambungan. Hal ini terlihat beberapa kelompok nelayan yang ada saat ini hanya sebatas terdaftar secara administrasi, namun keberadaan dan aktivitasnya hampir tidak ada, kalaupun ada masih sangat terbatas. Oleh karena itu, kegagalan pembangunan pada sektor kelautan dan perikanan yang umumnya banyak dijumpai di tiap daerah pesisirkarena belum siapnya lembaga di tingkat komunitas nelayan dalam menjalankan fungsinya tersebut. Fungsi kelompok nelayan belum maksimal dalam hal keterbatasan: 1) kemampuan dalam pengelolaan teknologi perikanan; 2) modal dalam usaha; 3 ) keterampilan yang rendah (skill).

\section{B. Permasalahan}

$\mathrm{K}$ ecamatan Tanjung Mutiara merupakan satu dari 16 kecamatan di Kabupaten Agam yang memiliki panjang pantai sekitar $43 \mathrm{~km}, 27 \mathrm{~km}$ per segi terumbuk karang dan 65 hektare hutan manggrov. Jumlah Nelayan di nagari Tiku Selatan dan nagari Tiku $\mathrm{V}$ Jorong, Kecamatan Tanjung Mutiara tercatat sekitar 1.952 orang dan aktif sekitar 1.750 orang dengan produksi ikan mencapai 3.415 ton/tahun dengan hasil tangkap jenis pelagis, udang dan teri (http://www.sumbarprov.go.id/index.php diakses tanggal 1 Januari 2013).

Kelompok-kelompok nelayan yang ada di kecamatan Tanjung Mutiara, khususnya di nagari Tiku Selatan saat ini berjumlah 21 kelompok nelayan. Dari 21 kelompok nelayan tersebut, diantaranya 13 kelompok yang berasal dari perikanan tangkap, sedangkan untuk 8 kelompok perikanan budidaya. Pada tahun 2012, kelompok-kelompok nelayan tersebut telah mendapatkan bantuan dana Pengembangan Usaha Mina Pedesaan (PUMP) perikanan tangkap dan budidaya dari Dinas Kelautan dan Perikanan Provinsi 
Sumatera Barat. Bantuan dana Pengembangan Usaha Mina Pedesaan (PUMP) ini bertujuan untuk mendorong program peningkatan produksi dan pemberdayaan masyarakat pembudidayaan ikan dan nelayan dalam rangka meningkatkan pendapatan, kesejahteraan dan dapat merubah pola hidup nelayan menjadi lebih baik.

Dengan kondisi tersebut diatas, menjelaskan bahwa kelembagaan nelayan terbentuk dari perilaku yang terus menerus hidup dalam komunitas nelayan, dan mengalami proses penyesuaian dengan adanya kendala-kendala yang dihadapi serta potensi lingkungannya. Kelembagaan yang ada pada komunitas masyarakat nelayan dimaksudkan sebagai suatu sistem organisasi yang berlaku dan diakui oleh komunitas nelayan, baik yang termasuk kelembagaan formal maupun informal (Astuty, 2006:115). Seperti halnya kelembagaan ekonomi dalam masyarakat nelayan terbentuk oleh adanya proses yang saling mempengaruhi antara lingkungan tempat hidup masyarakat dengan masyarakat itu sendiri (nelayan), dan peranan lembaga ini sangat berpengaruh terhadap berlangsungnya kegiatan ekonomi masyarakat nelayan diantaranya adalah nelayan tangkap (Astuty, 2006:116).

Kelembagaan bagi hasil bukan saja ditemukan pada masyarakat petani akan tetapi juga pada masyarakat nelayan telah lama dikenal. Kelembagaan atau sistem bagi hasil merupakan sistem informal yang eksis di masyarakat nelayan dan terbentuk dari tradisi yang telah ada di masyarakat nelayan. Pola bagi hasil ini muncul akibat dari ketidakpastian hasil tangkapan yang cenderung sangat berfluktuasi. Pola pendapatan nelayan yang tidak teratur sangat mempengaruhi corak adaptasi yang mereka lakukan. Adaptasi yang dilakukan nelayan terhadap usaha penangkapan ikan yang penuh spekulasi dan ketidakpastian melahirkan perilaku khusus yaitu yang disebut etika pemerataan resiko (Masyhuri, 2000).

Berdasarkan latar belakang tersebut diatas, maka penelitian ini melihat bagaimana gambaran kelembagaan sosial dan ekonomi nelayan dan strateginya dalam usaha meningkatkan ekonomi rumah tangganya di Nagari Tiku Selatan,
Kecamatan Tanjung Mutiara, Kabupaten Agam?

\section{Tinjauan Pustaka \\ 1. Pengertian Kelembagaan}

$\mathrm{K}$ elembagaan merupakan suatu sistem yang sengaja dibuat manusia untuk mengatur cara, aturan, proses dan peran masing-masing komponen pendukung di dalamnya untuk mencapai tujuan tertentu. Komponen pendukung di dalam suatu kelembagaan antara lain subjek atau orang sebagai penggerak sistem, segala aturan dan cara yang mengatur jalannya suatu sistem di dalam kelembagaan yang melibatkan banyak peran subjek tersebut.

Pengertian kelembagaan secara sosiologis, yaitu kelembagaan ibarat organorgan dalam tubuh manusia yang menjalankan masyarakat tersebut. Setiap fungsi dalam masyarakat pasti dijalankan oleh sebuah (atau lebih) kelembagaan. Untuk kebutuhan hidup, dalam hal berproduksi dan distribusi, dijalankan oleh kelembagaan ekonomi. Setiap orang yang terlibat di dalamnya diikat oleh suatu pola nilai dan norma sebagai pedoman bersikap dan berperilaku, yang dimantapkan kemudian dengan adanya struktur baku. Struktur merupakan visualisasi dari siapa orang yang terlibat dan posisionalnya.

Menurut Soekanto (2002), istilah kelembagaan diartikan sebagai lembaga kemasyarakatan yang mengandung pengertian abstrak perihal adanya normanorma dan peraturan-peraturan tertentu yang menjadi ciri lembaga tersebut. Sedangkan menurut Tjondronegoro dalam Pranadji (2003), pengertian tentang lembaga cenderung menyempitkan makna lembaga dengan pendekatan ciri kemajuan masyarakat. Soelaeman (1974) menuliskan bahwa kelembagaan dapat bertindak sesuai dengan kehendak masyarakat yang berperan besar terhadap sirkulasi kelembagaan tersebut. Sedikit berbeda dengan Rahardjo yang dikutip oleh Pasaribu (2007), konsep kelembagaan yang dianut oleh masyarakat menggunakan konsep lembaga sosial yang secara lebih sederhana diartikan sebagai kompleks norma-norma atau kebiasaankebiasaan untuk mempertahankan nilai- 
nilai yang dipandang sangat penting dalam masyarakat.

Berdasarkan beberapa pendapat tentang pengertian kelembagaan, dapat disimpulkan bahwa kelembagaan merupakan suatu sistem yang syarat dengan nilai dan norma yang bertujuan mengatur kehidupan manusia di dalam kelembagaan pada khususnya maupun manusia di luar kelembagaan pada umumnya. Norma-norma yang tumbuh dalam masyarakat memiliki tingkatan kekuatan mengikat tersendiri. Seperti yang dipaparkan Soekanto (2002) dalam Sosiologi sebagai Pengantar bahwa untuk dapat membedakan kekuatan mengikat norma-norma tersebut dikenal adanya empat pengertian, yaitu:

a. Cara (usage)

b. Kebiasaan (folksway)

c. Tata kelakuan (mores), dan

d. Adat istiadat (custom)

Setiap tingkatan di atas memiliki kekuatan memaksa yang semakin besar mempengaruhi perilaku seseorang untuk menaati norma. Begitu pula yang dipaparkan oleh Soemardjan Soelaeman (1974) bahwa setiap tingkatan tersebut menunjukkan pada kekuatan yang lebih besar yang digunakan oleh masyarakat untuk memaksa para anggotanya mentaati norma-norma yang terkandung didalamnya Kelembagaan adalah sekumpulan jaringan dari relasi sosial yang melibatkan orangorang tertentu, memiliki tujuan tertentu, memiliki aturan dan norma, serta memiliki struktur.

Kelembagaan dapat berbentuk sebuah relasi sosial yang melembaga (non formal institution), atau dapat berupa lembaga dengan struktur dan badan hukum (formal institution). Suatu relasi sosial dapat disebut sebagai sebuah kelembagaan apabila memiliki empat komponen, yaitu adanya: (1) Komponen aturan/kebijakan. Setiap kelembagaan mengembangkan seperangkat kesepakatan yang dipegang secara bersama, sehingga peran masingmasing yang terlibat dalamlembaga tersebut dapat kelihatan; (2) Komponen person (SDM). Orang-orang yangterlibat di dalam satu kelembagaan dapat diidentifikasi dengan jelas; (3) Komponen kepentingan (koordinasi). Orang-orang tersebut pasti sedang diikat oleh satu kepentingan atau tujuan, sehingga di antara mereka harus saling berinteraksi; dan, Komponen struktur/institusi dan tata laksana. Setiap orang memiliki posisi dan peran,yang harus dijalankannya secara benar. Orang tidak bisa merubah-rubah posisinyad engan kemauan sendiri.

\section{Kebudayaan Masyarakat Nelayan}

$\mathrm{S}$ ebagai suatu kesatuan sosial, masyarakat nelayan hidup, tumbuh, dan berkembang di wilayah pesisir atau wilayah pantai. Dalam konstruksi sosial masyarakat di kawasan pesisir, masyarakat nelayan merupakan bagian dari konstruksi sosial tersebut, meskipun disadari bahwa tidak semua desa-desa di kawasan pesisir memiliki penduduk yang bermatapencaharian sebagai nelayan. Walaupun demikian, di desa-desa pesisir yang sebagian besar penduduknya bermatapencaharian sebagai nelayan, petambak, ataupembudidaya perairan, kebudayaan nelayan berpengaruh besar terhadap terbentuknya identitas kebudayaan masyarakat pesisir secara keseluruhan (Ginkel, 2007, Kusnadi, 2010). Baik nelayan, petambak, maupun pembudidaya perairan merupakan kelompok-kelompok sosial yang langsung berhubungan dengan pengelolaan sumber daya pesisir dan kelautan.

Bagi masyarakat nelayan, kebudayaan merupakan sistem gagasan atau sistem kognitif yang berfungsi sebagai "pedoman kehidupan", referensi pola-pola kelakuan sosial, serta sebagai sarana untuk menginterpretasi dan memaknai berbagai peristiwa yang terjadi di lingkungannya (Keesing, 1989:68-69, Kusnadi, 2010)). Setiap gagasan dan praktik kebudayaan harus bersifat fungsional dalam kehidupan masyarakat. Jika tidak, kebudayaan itu akan hilang dalam waktu yang tidak lama. Kebudayaan haruslah membantu kemampuan survival masyarakat atau penyesuaian diri individu terhadap lingkungan kehidupannya. Sebagai suatu pedoman untuk bertindak bagi warga masyarakat, isi kebudayaan adalah rumusan dari tujuan-tujuan dan cara-cara yang digunakan untuk mencapai tujuan itu, yang disepakati secara sosial (Kluckhon, 1984:85-91, Kusnadi, 2010). Perspektif antropologis untuk memahami eksistensi suatu masyarakat bertitik tolak 
dan berorientasi pada hasil hubungan dialektika antara manusia, lingkungan, dan kebudayaannya. Karena itu, dalam beragam lingkungan yang melingkupi kehidupan manusia, satuan sosial yang terbentuk melalui proses demikian akan menampilkan karakteristik budaya yang berbeda-beda.

\section{Tujuan Dan Manfaat Penelitian}

$\mathrm{P}$ enelitian ini bertujuan untuk mengi dentifikasi kondisi kelembagaan sosial dan ekonomi nelayan dan strateginya sebagai upaya peningkatan ekonomi rumah tangga di Nagari Tiku Selatan, Kecamatan Tanjung Mutiara, Kabupaten Agam. dapat :

Melalui penelitian ini diharapkan

1. Mengembangkan penguatan kelembagaan yang dalam komunitas nelayan dalam upaya mempercepat proses pencapaian Millenium Development Goals (MDGs) atau tujuan pembangunan millennium di wilayah pesisir Kabupaten Agam.

2. Memecahkan masalah kelembagaan yang telah ada dalam komunitas nelayan, dari aspek sosial dan ekonomi melalui kultur masyarakat lokal berbasis komunitas pesisir khususnya nelayan.

3. Melalui hasil kajian ini, diharapkan dapat menemukan model pengembangan kelembagaan berdasarkan kultur masyarakat lokal berbasis komunitas, dalam rangka mendukung penanggulangan kemiskinan yang menjadi salah satu isu nasional.

4. Hasil penelitian sangat penting dilakukan sehingga menambah kepada bahan-bahan kajian ilmu Sosial, khususnya ilmu Antropologi.

\section{E. Metode Penelitian}

okasi penelitian dilaksanakan di Nagari Tiku Selatan, Kecamatan Tanjung Mutiara, Kabupaten Agam. Lokasi ini dipilih karena berada di wilayah pesisir pantai Barat Sumatera yang memiliki lebih dari 1.750 orang nelayan yang aktif dalam aktivitas perikanan dan kelautan. Dengan jumlah nelayan yang cukup besar tersebut terbentuklah 21 kelompok nelayan yang tersebar di nagari tersebut. Dalam kurun waktu 2 tahun terakhir, berbagai bantuan dari pihak pemerintah daerah Sumatera Barat melalui Dinas Kelautan dan Perikanan Provinsi Sumatera Barat datang ke kelompokkelompok nelayan tersebut dalam bentuk bantuan dana Pengembangan Usaha Mina Pedesaan (PUMP) yang bertujuan untuk mendorong program peningkatan produksi dan pemberdayaan masyarakat pembudidayaan ikan dan nelayan dalam rangka meningkatkan pendapatan, kesejahteraan dan dapat merubah pola hidup nelayan menjadi lebih baik.

Dengan bantuan yang diperoleh, dibuktikan bahwa dalam masyarakat nelayan di lokasi penelitian ini memiliki kelembagaan yang berdasarkan kultur masyarakat lokal yang cukup kuat, walaupun dalam perkembangannya kelembagaan tersebut terkesan sebagai alat kelengkapan proyek, belum sebagai wadah untuk pemberdayaan masyarakat secara hakiki. Akibatnya, eksistensi dan kinerjanya kurang mengembirakan, bahkan keberadaannya tidak berkesinambungan. Hal ini terlihat beberapa kelompok nelayan yang ada saat ini hanya sebatas terdaftar secara administrasi, namun keberadaan dan aktivitasnya hampir tidak ada, kalaupun ada masih sangat terbatas. Oleh karena itu, kegagalan pembangunan pada sektor kelautan dan perikanan yang umumnya banyak dijumpai di tiap daerah pesisirkarena belum siapnya lembaga di tingkat komunitas nelayan dalam menjalankan fungsinya tersebut.

Dalam penelitian ini menggunakan pendekatan penelitian kualitatif. Penelitian kualitatif memusatkan perhatian pada prinsip-prinsip umum yang mendasari perwujudan satuan-satuan gejala yang ada dalam kehidupan sosial. Dalam penelitian kualitatif yang dianalisis bukan variabelvariabel tetapi yang dianalisis dalam kaitan hubungan dengan prinsip-prinsip umum dari satuan-satuan gejala lainnya dengan menggunakan budaya masyarakat yang diteliti dan dari hasil analisis tersebut dianalisis lagi dengan menggunakan seperangkat teori yang berlaku (Neuman, 2006:149; Rudito, 2008: 78).

Teknik pengumpulan data yang telah dilakukan adalah menggunakan teknik observasi partisipasi, wawancara 
bebas dan mendalam dan studi kepustakaan. Pemilihan informan diambil secara purposive (sengaja), dimana pengambilan informan yang bersifat tidak acak dan juga berdasarkan pertimbanganpertimbangan tertentu yang dapat memberikan informasi sesuai dengan masalah yang diteliti. Informan yang telah dipilih adalah nelayan yang tergabung dalam 5 kelompok nelayan yang memiliki partisipasi yang aktif dalam kegiatan kelautan dan perikanan.

Data-data yang telah dikumpulkan oleh peneliti termasuk juga catatan lapangan dikelompokkan oleh peneliti atas dasar aktivitas khusus yang ada dan diteliti. Kemudian dari pengelompokkan data tersebut, data-data itu kemudian diabstraksikan dan dikaitkan satu dengan lainnya sebagai satu kesatuan kejadian dan fakta yang terintegrasi. Dari abstraksi tersebut maka akan tampak pranata sosial yang berlaku di wilayah atau komuniti tersebut (Bungin, 2004:60).

Dalam menganalisis tentunya selalu terkait dengan konsep yang telah dipelajari sebelumnya. Sehingga dari hasil analisis akan tampak kesesuaian dari data yang diperolehnya dengan konsep yang dipelajarinya atau akan berbeda dengan konsep yang dipelajarinya karena masalah sosial akan selalu berbeda antara satu masyarakat dengan masyarakat lainnya.

Setelah itu disusun sesuai dengan kategori-kategori dan kemudian disimpulkan. Apabila dalam kesimpulan masih menimbulkan keraguan maka dilakukan pengkategorian ulang hingga seluruh data yang telah berhasil dikumpulkan dianggap sesuai dengan tujuan penelitian. Temuan di lapangan akan diolah dengan data yang didapat dari literatur dan akan disajikan dalam suatu karya etnografi deskriptif.
F. Hasil Dan Pembahasan

1. Gambaran Umum Nagari Tiku Selatan

N agari $^{5}$ Tiku Selatan terletak di Kecamatan Tanjung Mutiara, Kabupaten Agam, Sumatera Barat. Nagari Tiku Selatan terdiri dari 7 jorong ${ }^{6}$, yang terdiri: (1) Jorong Gasan Kaciak dengan luas wilayah $1.141 \mathrm{Ha}$; (2) Jorong Banda Gadang dengan luas wilayah 724 $\mathrm{Ha}$; (3) Jorong Pasa Tiku dengan luas wilayah $111 \mathrm{Ha}$; (4) Jorong Pasia Tiku dengan luas wilayah $100 \mathrm{Ha}$; (5) Jorong Kampung Darek dengan luas wilayah 520 $\mathrm{Ha}$; (6) Jorong Pasia Paneh dengan luas wilayah $605 \mathrm{Ha}$; dan (7) Jorong Sungai Nibuang dengan luas wilayah $385 \mathrm{Ha}$.

Jumlah jorong yang berada di daerah pesisir sebanyak 4 buah (21\%) dan jorong bukan pesisir sebanyak 15 buah (79\%), dengan jumlah penduduk pesisir dengan mata pencaharian sebagai nelayan sebanyak 2.152 KK (2\%). Nagari Tiku Selatan berbatasan sebelah utara dengan Nagari Tiku V Jorong, sebelah Selatan dengan Nagari Batang Gasan, sebelah Barat berbatasan dengan Samudra Indonesia dan sebelah Timur berbatasan dengan Nagari Tiku Utara.

Nagari Tiku Selatan memiliki ketinggian tempat berkisar $2 \mathrm{~m}$ dari permukaan laut dengan suhu rata-rata sekitar $26^{\circ} \mathrm{C}-30^{\circ} \mathrm{C}$ dengan rata-rata curah hujan $2000 \mathrm{~mm}$. Wilayah ini terdiri dari dataran rendah, dengan tinggi pesisir pantai yang rendah. Pada abad 18an, Tiku adalah salah satu tempat pelabuhan besar di daerah Minangkabau. Salah satu bukti sejarah disana adalah gaya pakaian "marapulai", dimana gaya berpakaian marapulai sama seperti yang di pakai para matador di spanyol. Kaos kaki tinggi dan

\footnotetext{
${ }^{5}$ Nagari sendiri berasal dari bahasa Sansekerta, dalam bahasa Indonesia berarti kota (ibu kota), istana dan negara atau kerajaan sehingga Minangkabau nagari sering disebut dengan "republik kecil". Nagari adalah pembagian wilayah administratif di propinsi Sumatera Barat di bawah kecamatan yang dipimpin oleh seorang wali nagari.

6 Jorong adalah satu kesatuan di dalam masyarakat yang tinggal di suatu daerah tertentu. Setiap jorong memiliki pemimpin yang disebut wali Jorong yang berada di bawah pemerintahan nagari.
} 
rompi merupakan salah satu bukti sejarah bahwa ketika Portugis meninggalkan Tiku. Kata Tiku sendiri berasal dari Tako atau Teko, artinya tempat penampungan. Ini artinya bahwa Tiku di jadikan sebagai tempat logistik para penjajah. (http://nanangsarfinal.blogspot.com/2008/0

9/sisa-sejarah-tiku.html diakses tanggal 17 Oktober 2013).

Kabupaten Agam mempunyai sejarah yang panjang dan komplit, baik di bidang Pemerintahan maupun di bidang adat istiadat. Diawali dari Kerajaan Minangkabau pada pertengahan abad ke17, dimana rakyat Minangkabau telah memanggul senjata untuk berontak melawan penjajahan Belanda. Pemerintahan Minangkabau yang disebut Ranah Minang, dimana Kabupaten Agam tempo dulu, selain Sumatera Barat juga termasuk daerah Limo Koto Kampar (Bangkinang) yang sekarang termasuk Propinsi Riau, Daerah Kabupaten Kerinci (Sungai Penuh) sekarang termasuk Propinsi Jambi dan sebagian daerah Tapanuli Selatan (Koto Napan) yang sekarang secara administrasi berada di Propinsi Sumatera Utara. Pemerintahan adat mencakup Luhak dan Rantau, dimana Pemerintahan Wilayah Luhak terdiri dari Luhak Tanah Datar, Luhak Limo Puluah dan Luhak Agam. Komisariat Pemerintahan Republik Indonesia di Sumatera yang berkedudukan di Bukittinggi mengeluarkan peraturan tentang pembentukan daerah Otonom Kabupaten di Sumatera Tengah yang terdiri dari 11 Kabupaten yang salah satunya Kabupaten Singgalang Pasaman dengan ibukotanya Bukittinggi yang meliputi kewedanan Agam Tuo, Padang Panjang, Maninjau, Lubuk Sikaping dan Kewedanaan Talu ( kecuali Nagari Tiku, Sasak dan Katiagan).

Dalam masa Pemerintahan Belanda, Luhak Agam dirubah statusnya menjadi Afdeling Agam yang terdiri dari Onder Afdeling Distrik Agam Tuo, Onder Afdeling Distrik Maninjau dan Onder Afdeling Distrik Talu. Pada permulaan Kemerdekaan RI tahun 1945 bekas Daerah Afdeling Agam dirubah menjadi Kabupaten Agam yang terdiri dari tiga kewedanan masing-masing Kewedanaan Agam Tuo, Kewedanaan Maninjau dan Kewedanaan Talu.
Dengan Surat Keputusan Gubernur Militer Sumatera Tengah No. 171 tahun 1949, daerah Kabupaten Agam diperkecil dimana Kewedanaan Talu dimasukkan ke daerah Kabupaten Pasaman, sedangkan beberapa nagari di sekitar Kota Bukittinggi dialihkan ke dalam lingkungan administrasi Kotamadya Bukittinggi. Keputusan Gubernur Militer Sumatera Tengah tersebut dikukuhkan dengan Undang-undang No. 12 tahun 1956 tentang pembentukan Daerah Tingkat II dalam lingkungan Propinsi Sumatera Tengah, sehingga daerah ini menjadi Daerah Tingkat II Kabupaten Agam. Pada tanggal 19 Juli 1993 secara de facto, ibukota Kabupaten Agam telah berada di Lubuk Basung yang dikuatkan dengan dikeluarkannya Peraturan Pemerintah Republik Indonesia (PP Nomor 8 Tahun 1998) (http://agammedia.blogspot.com/ 2011/09/sejarah-dansosiologi.html diakses tanggal 17 Oktober 2013).

Menurut silsilah (ranji), kaum keturunan Datuk Rangkayo Basa (DRB) di Kanagarian Tiku berasal dari sebuah perkampungan kaum suku Jambak bernama Galo Gandang di Tanah Data. Salah seorang dari kaum ini, pada masa yang tidak teridentifikasi, merantau ke pesisir barat bernama Puti Sanang Hati dengan membawa empat orang anaknya, tiga perempuan dan seorang laki-laki. Anak yang pertama bernama Puti Ambat, yang kedua bernama Puti Langgam, yang ketiga adalah laki-laki yang bernama Sutan Mara Basa, serta yang bungsu bernama Puti Manis. Menurut ranji yang saat ini masih disimpan oleh kaum keluarga DRB di Galo Gandang Tanah Data, Puti Sanang Hati mempunyai empat orang anak, namun nama anak-anak tersebut tidak disebutkan karena ranji mereka putus sampai Puti Sanang Hati saja, namun hanya tertera bahwa Puti Sanang Hati memiliki empat orang anak, satu diantaranya adalah lakilaki.

Dalam dalam ranji keluarga DRB di Tiku, nama-nama kaum keluarga ini tercatat dengan baik. Sehingga singkatnya untuk menjaga tali hubungan darah ini tidak putus, maka pada masa itu DRB pun dilewakan di nagari rantau pesisir ini. Sutan Mara Basa sebagai satu-satu anak lelaki dalam kaum ini dilewakan gelar Datuk Rangkayo Basa. Karena ciri-ciri dari Sutan 
Mara Basa ini orangnya tinggi berdada cekung, maka beliau juga disebut oleh orang sebagai Datuk Rangkayo Basa nan Cakuang Dado (Di samping tersebutkan pada ranji, tanda kebenaran kaum keturunan ini berasal dari kaum keluarga Jambak Galo Gandang Tanah Data dapat dilihat pada pandam pekuburan kaum Jambak di Jawi-jawi Tiku yang batu nisannya berasal dari kerajinan Galo Gandang Tanah Data. Menurut kisah yang siriwayatkan oleh para tuo-tuo kaum suku jambak, Sutan Mara Basa bergelar datuk Rangkayo Basa (nan cakuang dado) terkenal karena berbagai keistimewaan yang dimilikinya sehingga hal ini membuatnya sangat disegani di dalam dan di luar nagari Tiku.

Sehingga selain gelar Datuk Rangkayo Basa merupakan gelar sako kaum jambak juga merupakan gelar pemimpin dalam kanagarian Tiku yang menaungi suku-suku lainnya di kanagarian Tiku. Hal ini terlihat dari kepemimpinanpemimpin penyandang gelar sako DRB di Tiku yang semuanya merupakan wali nagari kanagarian Tiku. Ranji DRB di kanagarian Tiku (pesisir barat) yang asli dibuat dalam tulisan arab, sama halnya dengan ranji yang asli yang ada di tangan kaum kelurga DRB di Galo Gandang Tanah Data. Kemudian oleh salah seorang cucu kemenakan St Mara Basa Datuk Rangkayo Basa yang bernama Haji Abdul Wahab atau Buyuang Enek (bergelar Sutan Badar Alam), ranji bertulisan arab ini dibuatkan ke dalam bahasa latin (Indonesia), sementara ranji yang asli bertulisan arab tersebut masih disimpan dengan baik.

$$
\text { Dalam sistem kekerabatan }
$$

matriakhat di Minangkabau, sako dan pusako diwariskan secara turun temurun menurut garis ibu. Kawasan pusako kaum keluarga suku Jambak ini meliputi daerah Jawi-jawi sampai ke Cacang (Tiku). Demikian pula halnya, ketika Sutan Mara Basa bergelar Datuk Rangkayo Basa memasuki masa purna tugas sebagai pemegang sako tinggi kaum keluarga suku Jambak, maka sako ini pun diteruskan oleh kemenakan dan cucu-cucu kemenakannya yang semuanya juga menjadi pimpinan di kanagarian Tiku. Dalam ranji kaum ini dapat ditemui nama-nama cucu kemenakan yang meneruskan sako kaum ini. Cuku kemenakan yang terakhir memegang gelar sako Datuk Rangkayo Basa ini bernama Sutan Tamin, juga wali nagari Tiku. Namun ketika Sutan Tamin Datuk Rangkayo Basa wafat sekitar tahun 1970, gelar sako ini tidak dapat terselenggarakan lagi dengan baik karena kemenakan yang seharusnya melanjutkan kepemimpinan kaum keluarga, diantaranya H Abdul Wahab bergelar Sutan Badar Alam, berada diperantauan.

Namun agar tanda pusako dan identitas kaum Jambak kanagarian Tiku keturunan kaum keluarga Datuk Rangkayo Basa tidak hilang, semasa hidupnya Sutan Badar Alam telah memugar pandam pakuburan kaum Jambak yang terletak di Simpang Tiga Jawi-jawi Tiku dan bangunan rumah gadang yang teletak di Jawi-jawi (tidak jauh dari pandam pakuburan ini) direhabilitasi dan sebagian tanahnya dijadikan bagunan sebuah mesjid yang bernama Nurul Wahab. Pada pandam pakuburan kaum ini terbaringlah Puti Sanang Hati dan anak-anaknya termasuk Sutan Marah Basa Datuk Rangkayo Basa serta semua generasi kaum suku Jambak kanagarian Tiku kaum keturunan Datuk Rangkayo Basa yang berasal dari Galo Gandang Tanah Data ini.

Sako Datuk Rangkayo Basa sudah tidak dilewakan lagi semenjak meninggal Sutan Tamin sebagai pewaris yang terakhir, walau ada upaya dari berbagai pihak untuk meminjamnya. Di samping itu, berbagai perkembangan situasi politik telah menyebabkan pula berbagai hal terjadi pada gelar sako DRB ini. Datuk Rangkayo Basa boleh tiada, namun semangat dalam membangun kampung dan kaum keluarga seperti yang pernah dilakukan oleh pemangku-pemangku sako Datuk Rangkayo Basa masih melekat di dalam jiwa setiap anggota kaum keluarga, baik yang masih berada di kampung maupun yang di perantauan (http://pusakampa.blogspot.

com/2009/06/suku-jambak-sejarah-ringkas. $\mathrm{html}$ diakses tanggal 17 Oktober 2013).

Berdasarkan data kependudukan Nagari Tiku Selatan tahun 2012, jumlah penduduk sebanyak 13.003 jiwa orang, dengan penduduk laki-laki berjumlah 6.699 jiwa dan penduduk perempuan 6.304 jiwa orang. Jumlah kepala keluarga (KK) adalah 2.608. Berdasarkan hasil wawancara diperoleh bahwa jumlah penduduk 
terbanyak di Nagari Tiku Selatan yang dikategorikan pada usia produktif berada pada tingkat umur antara 20 tahun hingga 50 tahun. Hal tersebut terkait erat dengan berbagai pekerjaan yang ditekuni oleh masyarakat di Nagari Tiku Selatan.

Dalam pemenuhan kebutuhan hidup masyarakat di Nagari Tiku Selatan, baik kebutuhan dasar seperti kebutuhan sandang, pangan dan papan maupun kebutuhan sekunder seperti kebutuhan pendukung lainnya sangat diperlukan mata pencaharian untuk mencapai usaha tersebut. Dalam pemenuhan kebutuhan tersebut, di dalam masyarakat mempunyai mata pencaharian yang beragam/bervariasi. Demikian juga dengan masyarakat Nagari Tiku Selatan yang memiliki beragam mata pencaharian. Sebagian besar penduduk di Nagari Tiku Selatan bermata pencaharian sebagai petani, buruh dan nelayan, terutama nelayan buruh sebanyak 145 (11\%). Salah satu penyebabnya adalah kondisi wilayah Nagari Tiku Selatan yang terletak memanjang di garis pantai daerah Nagari Tiku Selatan.

Pendidikan merupakan kebutuhan utama masyarakat di Nagari Tiku Selatan sebagai usaha untuk menambah ilmu pengetahuan mereka dan juga mengangkat pada derajat yang lebih tinggi. Kesadaran masyarakat di Nagari Tiku Selatan terhadap pentingnya pendidikan cukup tinggi dimana sebagian besar masyarakatnya sudah mengenyam pendidikan padan tingkat SMP dan SMA. Meskipun demikian, sebagian masyarakatnya juga ada yang menamatkan pendidikan hanya pada tingkat SD. Berdasarkan tingkat pendidikan di Nagari Tiku Selatan dikatakan sudah cukup tinggi. Hal tersebut diperlihatkan melalui jumlah penduduk yang telah menamatkan pendidikan SD, SMP, SMA dan perguruan tinggi sebanyak 6.350 (90\%). Meskipun demikian, diperoleh juga terdapat penduduk yang tidak menamatkan pendidikan SD (10\%). Pada umumnya, mereka yang tidak menamatkan pendidikan SD dikarenakan faktor ekonomi dan kesempatan.

Untuk menunjang aktivitas pendidikan masyarakat di Nagari Tiku Selatan sangat dibutuhkan sarana dan prasarana agar tujuan pendidikan dapat tercapai dengan jumlah sarana pendidikan di Nagari Tiku Selatan cukup memadai dengan tersedianya sarana pendidikan SMP dan SMA. Hal tersebut diperlihatkan dari tingkat pendidikan yang cukup tinggi dengan tingkat pendidikan SMP dan SMA.

\section{Pola Pemukiman Nagari Tiku Selatan}

$\mathrm{P}$ ola pemukiman adalah wujud dari bentuk pemukiman pada suatu daerah yang meliputi pola letak tempat tinggan dan bentuk rumah di pemukiman tersebut. Pola letak pemukiman di Nagari Tiku Selatan tidak berbeda jauh dengan pola pemukiman wilayah pesisir di daerah lain, dimana rumah-rumah membentang sepanjang pantai di pesisir pantai Tiku.

Pola pemukiman Nagari Tiku Selatan yang mengikuti garis pantai dimulai dari Jorong Gasan Kaciak , kemudian dilanjutkan menuju Jorong Banda Gadang, Jorong Pasa Tiku dan Jorong Pasia Tiku. Untuk 3 jorong lainnya berada di sepanjang perbukitan yang berada di seberang garis pantai. Untuk menuju Nagari Tiku Selatan, dapat ditempuh dengan kendaraan beroda dua dan empat dengan sarana jalan yang cukup baik sehingga dapat ditempuh selama 1.5 jam perjalanan dari ibu kota Sumatera Barat, yaitu kota Padang.

Kepemilikan rumah yang berada di sekitar pantai adalah sebagian besar dimiliki oleh rumah tangga nelayan buruh dan juga pedagang ikan berskala kecil. Pada umumnya, bentuk rumah di Nagari Tiku Selatan, terutama kampung-kampung di sekitar pantai terdiri dari rumah tidak permanen dan semi permanen dan hanya beberapa rumah saja yang permanen, yaitu sekitar 5-10 rumah. Untuk rumah-rumah yang berada di sekitar jalan utama yang menghubungkan antar jorong di Nagari Tiku Selatan, keadaannya lebih baik dari rumah yang ada di dekat pantai. Biasanya rumah-rumah di wilayah ini dihuni oleh pedagang ikan dengan skala yang lebih besar dibandingkan dengan pedagang yang ada di pinggir pantai.

Berdasarkan observasi (melalui pengamatan), terdapat beberapa rumah di pemukiman sekitar wilayah pantai (5-10 rumah) yang dihuni oleh para nelayan yang tidak layak untuk menjadi tempat tinggal. 
Rumah mereka hanya beralaskan pasir pantai dan berdindingkan kayu dan juga atapnya terbuat dari seng yang sudah berkarat dan berlubang.

Di sekitar pemukiman nelayan, terdapat 2-4 warung makanan yang selalu dipenuhi oleh para nelayan buruh, terutama sekali ketika mereka sudah selesai melaksanakan aktivitas penangkapan ikan seperti memukat dan juga pada saat terjadinya badai (cuaca tidak baik). Aktivitas yang biasa mereka lakukan adalah berdiskusi tentang aktivitas penangkapan ikan, bermain domino/kartu dan hanya sekedar minum kopi.

\section{Aktivitas Sosial Budaya Masyarakat}

$\mathrm{M}$ asyarakat nagari Tiku Selatan menganut sistem kekerabatan matrilineal, yakni kekerabatan mengacu kepada garis keturunan perempuan. Tradisi sosial yang paling unik di nagari ini adalah tradisi perkawinan dan kematian. Tradisi perkawinan adalah perempuan 'membeli' laki-laki, artinya perempuan yang membayar biaya dan mahar perkawinan. Dalam tradisi ini ada konsep uang 'hilang' dan uang 'menjemput'. Uang hilang adalah uang yang digunakan untuk mengganti pengeluaran orangtuanya dalam membesarkan anak laki-lakinya baik berupa uang atau barang seperti motor atau mobil. Penggantian uang hilang ini tergantung kepada tingkat pendidikan dan pekerjaan laki-laki tersebut, apabila tinggi pendidikannya maka semakin tinggi uang hilangnya. Untuk uang menjemput adalah uang yang dibayar ketika menjemput lakilaki saat pelaksanaan pernikahan, dengan uang menjemput berupa ringgit sebanyak 12 emas. Dalam tradisi perkawinan ini didalamnya terdapat prosesi seperti adat menurunkan pengantin perempuan dari rumah ibunya (bundo kanduang), adanya upacara mencukur rambut, "balatui badia', adat menjemput pengantin laki-laki (bagalombang duo baleh).

Selain tradisi perkawinan, tradisi kematian di wilayah ini terbilang unik. Tradisi kematian disebut dengan istilah 'batagak adat' dengan cara 'Bejamba', yaitu masing-masing keluarga, tetangga dan kerabat dalam satu suku yang melayat membawa makanan yang kemudian ditumpuk-tumpuk menjadi sebuah gunung makanan hingga mencapai lebih kurang 2 meter. Setelah makanan menggunung, maka dilaksanakan acara berdoa (zikir) bersama, setelah itu dilakukan kegiatan membagi-bagi harta warisan, "malewang gala", upacara doa setelah $3,7,14,40$ dan 100 hari kematian anggota keluarga.

\section{Aktivitas Ekonomi Perikanan Masyarakat}

ktivitas ekonomi perikanan yang
dilakukan oleh nelayan pada
umumnya dilakukan secara berkelompok tetapi ada juga yang melakukannya secara perorangan. Kegiatan tersebut sebagian besar dilakukan oleh pihak laki-laki yang berumur diatas 15 tahun. Pendapatan nelayan di nagari Tiku Selatan berkisar antara Rp.25.000,- hingga Rp. 100.000,-Pendapatan nelayan termasuk rendah dikarenakan sebagian besar nelayan di nagari Tiku Selatan tersebut adalah nelayan buruh (60\%). Aktivitas penangkapan ikan pada masyarakat nelayan Nagari Tiku Selatan, yaitu aktivitas membagan, memayang, memukat dan menjaring. Teknologi pada penangkapan ikan menjaring menggunakan peralatan jaring dan perahu. Jaring yang selalu dipergunakan oleh masyarakat nelayan Nagari Tiku Selatan adalah yang berukuran 100-200 m. Jaring ini ada yang jahitannya halus dan kasar. Jaring yang halus ukuran matanya memiliki panjang $25-20 \mathrm{~cm}$ dan lebarnya kira-kira $5 \mathrm{~cm}$, sedangkan jaring yang jahitannya kasar ukuran matanya memiliki panjang $50-60 \mathrm{~cm}$ dan lebar 10 $\mathrm{cm}$. Untuk jahitan yang kasar adalah untuk menangkap ikan yang besar-besar seperti ikan gembolo, ikan gurigak, belatuk dan soaso, sedangkan jahitan yang halus atau rapat adalah untuk menangkap ikan yang kecil-kecil seperti ikan campu, pinangpinang, maco dan tete. Untuk menangkap ikan dengan menjaring mempergunakan sebuah perahu yang panjangnya lebih kurang $4 \mathrm{~m}$ dan lebarnya $1 \mathrm{~m}$. Perahu yang banyak digunakan oleh masyarakat nelayan Nagari Tiku Selatan saat ini sudah banyak memakai mesin perahu/mesin tempel.

Hasil tangkapan ikan yang diperoleh langsung di bawa ke pasar tradisional Tiku 
Selatan dan disana sudah ada agen atau pembeli yang menanti. Biasanya agenagen tersebut telah ditentukan oleh induk semang. Alasan lain nelayan menjual ikan di pasar tradisional Tiku Selatan karena semua jenis ikan dapat diterima baik besar maupun kecil, begitu juga dengan jenisjenisnya.

Nagari Tiku Selatan merupakan Nagari yang memiliki potensi sumber daya alam yang cukup banyak dilihat dari berbagai aspek seperti Nagari Tiku Selatan mempunyai wilayah laut yang dengan garis pantai sepanjang $\pm 6 \mathrm{~km}$ dan disertai dengan Tempat Pendaratan Ikan (TPI) beserta fasilitas penunjang lainnya. Potensi hasil laut nagari Tiku Selatan telah menjadi salah satu andalan ekonomi yang utama dari nagari Tiku Selatan.

Dari segi infrastruktur dan perhubungan Nagari Tiku Selatan dilalui oleh jalan negara yang menghubungkan Ibukota Propinsi dan lbukota Kabupaten. Ditambah dengan beradanya ibukota Kecamatan Tanjung Mutiara di Nagari Tiku Selatan, maka hampir seluruh kantor instansi pemerintah dan swasta serta sekolah-sekolah berada di Nagari Tiku Selatan. Dari Segi Ekonomi otomatis dengan keberadaan TPI dan pasar serikat , maka seluruh aktifitas utama perikanan dan ekonomi berada di Nagari Tiku Selatan . Ditambah dengan keberadaan kantor beberapa Bank BPR dan bank umum, Koppem serta BMT yang terletak di Nagari Tiku Selatan yang sangat membantu pertumbuhan ekonomi masyarakat. Dari segi sumber daya manusia Nagari Tiku Selatan mempunyai asset SDM yang cukup banyak dengan tingkat pendidikan yang cukup tinggi serta mempunyai beragam keahlian. Namun potensi tersebut belum tergali dan dimanfaatkan secara maksimal.

\section{Gambaran Nelayan di Nagari Tiku Selatan}

$\mathrm{K}$ elompok-kelompok nelayan yang dibentuk terbagi ke dalam 5 pengelompokkan kelembagaan, yaitu kelompok penangkapan ikan, pengolahan ikan, budidaya ikan lele, kelompok usaha bersama dan kelompok pengawas masyarakat.

Berdasarkan klasifikasi Masyuri dalam Lucky Zamzami (2009:39) bahwa ciri-ciri nelayan buruh atau dikatakan nelayan tradisional ditandai dengan (a) kegiatan mereka yang lebih banyak menggunakan padat, kalaupun menggunakan mesin, ukuran atau tenaga mesin relatif kecil atau motor tempel dengan menggunakan alat tangkap yang sederhana; (b) teknologi yang dipakai untuk penangkapan atau pengolahan ikan yang masih sederhana dan (c) tingkat pendidikan dan keterampilan yang rendah. Ciri-ciri tersebut diatas dibuktikan dengan peralatan penangkapan ikan yang sederhana seperti perahu (biduak) yang memakai mesin tempel, alat pancing/jala sehingga hasilnya sangat berbeda jauh dengan peralatan nelayan modern.

Keterbatasan potensi serta modal usaha nelayan di Nagari Tiku Selatan yang memiliki pengertian nelayan yang bekerja dengan alat tangkap milik orang lain. Mereka harus membagi hasil tangkapannya dengan nelayan juragan (yang memiliki peralatan) sampai $65 \%$ dengan pembagian $50 \%$ untuk nelayan juragan dan $15 \%$ untuk mengatasi kerusakan.

Aktivitas penangkapan ikan yang dilakukan oleh nelayan Nagari Tiku Selatan hampir sama dengan aktivitas penangkapan ikan lainnya di berbagai daerah di wilayah pantai Barat Sumatera. Aktivitas penangkapan ikan yang dilakukan oleh nelayan buruh di wilayah pesisir pantai Selatan Sumatera Barat adalah membagan, memayang, memukat, menjaring dan memancing (Zamzami, 2008,2009).

Salah satu faktor penting dalam aktivitas nelayan Nagari Tiku Selatan adalah menjual hasil penangkapan ikan. Hasil produksi berupa ikan yang telah ditangkap di laut oleh nelayan buruh merupakan produksi ikan yang cepat rusak sehingga harus segera dipasarkan. Kondisi ini menyebabkan para nelayan buruh menjual hasil tangkapannya secepatnya setelah berlabuh di tepi pantai. Biasanya hasil tangkapan para nelayan buruh akan langsung dijual di pinggir pantai, dimana di tempat tersebut telah menunggu para pedagang (toke') dan juga pengolah ikan untuk membeli hasil tangkapan mereka. Dalam proses penjualan ikan tersebut, nelayan buruh langsung berhubungan 
dengan para pedagang atau pengolah ikan tanpa ada perantara.

Harga ikan yang dijual oleh nelayan di Nagari Tiku Selatan bervariasi sesuai dengan jenis ikan yang ditangkap, yaitu:

a. Ikan Bulato (ikan Kembung) $1 \mathrm{~kg}$ seharga Rp. 13.000,-

b. Ikan Gabua 1 kg seharga Rp. 15.000,-

c. Ikan Kaliang-kaliang $1 \mathrm{~kg}$ seharga Rp. 7.000,-

d. Ikan Tongkol $1 \mathrm{~kg}$ seharga Rp. 10.000,-

e. Ikan Tambolo $1 \mathrm{~kg}$ seharga Rp. 14.000,-

f. Ikan Bowl putih $1 \mathrm{~kg}$ seharga Rp.40.000,-

g. Ikan Bowl hitam $1 \mathrm{~kg}$ seharga Rp.20.000,-

h. Ikan Tenggiri Aceh $1 \mathrm{~kg}$ seharga Rp. 20.000,-

i. Ada juga terdapat pengolahan bada teri (ikan teri), namun jarang karena ikan teri lumayan sulit di dapat.

Untuk aktivitas penangkapan ikan yang dilakukan oleh nelayan di Nagari Tiku Selatan terdapat beberapa perahu yang digunakan dalam mencari ikan, yaitu:

a. Kapal Bagan, kapal yang cukup besar menggunakan mesin sebagai penggerak kapal, dan memiliki lampu sebagai penarik ikan. Biasanya kapal bagan dapat ditemukan di daerah Suranti.

b. Kapal Tondo atau kapal boat, yaitu kapal dengan mesin disel seperti boat.

c. Pompong, kapal yang menggunakan tenda

d. Payang, yaitu biduak atau perahu bercadik.

e. Robin, yaitu perahu dengan menggunakan mesin robin atau mesin tempel seperti speedboat. Biasanya hanya untuk 2 orang.

f. Sampan Boling yaitu sampan biasa dengan menggunakan dayung saja.

Untuk aktivitas penangkapan ikan di Nagari Tiku Selatan, terdapat hari di mana para nelayan buruh tidak diperbolehkan melaut, yaitu pada hari jum'at. Pada hari Jum'at tersebut para buruh nelayan hanya fokus beribadah (shalat Jum'at) terutama bagi yang laki-laki dimana kalau ada yang melanggar maka nelayan buruh yang melakukan akan mendapatkan sanksi sosial seperti cemoohan dari masyarakat. Kemudian saat ada kematian, buruh nelayan harus melayat ke rumah jenazah dan mengikuti proses-proses upacara kematian sebagai penghormatan kepada orang yang sudah meninggal.

Biasanya para nelayan Nagari Tiku Selatan ketika ke laut dilakukan pada pagi hari sekitar pukul $06.30 \mathrm{Wib}$, kemudian kembali pada pukul 16.00 Wib. Kegiatan tersebut dikatakan tidak menentu dimana tergantung kepada hasil tangkapan ikan. Untuk melakukan penangkapan ikan pada malam hari, tidak banyak dilakukan oleh para nelayan buruh dikarenakan kondisi fisik nelayan buruh dan penggunaan perahu sebatas payang dan perahu tanpa mesin.

\section{Lembaga-Lembaga Sosial: Yasinan/Wirid Pengajian, Arisan}

$\mathrm{K}$ elembagaan tradisional yang masih hidup di Nagari Tiku Selatan adalah kelompok sosial pengajian, arisan ibu-ibu dan yasinan, masih berjalan dengan baik. Partisipasi rumah tangga terhadap kelompok sosial juga sangat baik. Hampir seluruh ibu-ibu terlibat dalam kegiatan rutin kelompok tersebut. Pengajian dan yasinan dilaksanakan setiap minggu secara bergilir dari rumah ke rumah. Sedangkan arisan dilaksanakan setiap dua minggu.

Strategi sosial dilakukan dengan jalan memanfaatkan ikatan-ikatan sosial yang ada di perdesaan baik berupa lembaga kesejahteraan lokal, hubungan produksi hingga jejaring sosial berbasis kekerabatan atau pertemanan. Rasa percaya antar warga (trust) sangat tinggi. Rasa percaya antar warga yang tinggi ini menyebabkan pola hutang-piutang antar rumah tangga dapat berjalan dengan baik. Pentingnya kepercayaan pribadi dalam mempertahankan modal sosial. Hutang menjadi salah satu bentuk strategi nafkah bagi rumah tangga miskin. Untuk berhutang mereka memanfaatkan jejaring sosial yang ada, seperti ikatan kekerabatan, pertetanggaan atau pertemanan. Hutang digunakan untuk memenuhi kebutuhan hidup sehari-hari atau kebutuhan yang mendesak seperti ketika anggota rumah tangga ada yang sakit. Jarang sekali hutang digunakan 
untuk keperluan pembelian barang konsumtif.

Modal sosial merupakan salah satu andalan bagi rumah tangga miskin. Ikatan kekerabatan, pertetanggaan dan pertemanan yang kuat memberikan ruang yang cukup bagi rumah tangga miskin untuk mengakses modal sosial ini. Keterlibatan rumah tangga miskin dalam kelembagaan kesejahteraan lokal cukup tinggi. Di Nagari Tiku Selatan tidak ada diskriminasi peran dalam kehidupan sosial kemasyarakatan bagi rumah tangga miskin. Pola relasi yang cenderung egaliter menyebabkan rumah tangga miskin dapat dengan mudah mengakses berbagai bentuk kelembagaan lokal ini. Bagi rumah tangga miskin, modal sosial merupakan aset yang sangat penting karena melalui modal sosial mereka dapat mengakses berbagai bentuk modal yang lain.

Tingkat partisipasi masyarakat, utamanya ibu-ibu di dalam kelompok cenderung tinggi. Tingkat kepercayaan dan solidaritas antar warga cukup tinggi. Hal ini dibuktikan dengan bertahannya lembaga tradisional seperti gotong royong. Tingkat kepercayaan antar warga yang tinggi juga tampak dari hutang piutang antar warga yang berjalan dengan lancar. Kelompok sosial yang ada di Nagari Tiku Selatan beranggotakan masyarakat yang berasal dari dalam nagari. Akses terhadap sumber daya dan informasi dari luar masih terbatas. Modal sosial masih terbatas digunakan untuk pemenuhan kebutuhan jangka pendek (konsumtif), belum mengarah pada pemenuhan kebutuhan jangka panjang (produktif). Modal sosial belum dimanfaatkan untuk menunjang kegiatan-kegiatan produktif karena keterbatasan modal manusia dan modal finansial. Kegiatan kelompok yang terbatas pada dimensi sosial religius perlu dikembangkan ke arah ekonomi. Kegiatan produktif dapat dikembangkan secara bersama-sama oleh masyarakat. Tingkat kepercayaan antar warga yang tinggi sangat bermanfaat untuk memulai kegiatan simpan pinjam dan merintis usaha melalui modal bersama.

Dalam seluruh aktivitas yang berkaitan dengan arisan merupakan gejala umum yang dipraktikkan hampir oleh setiap penduduk nelayan di Nagari Tiku Selatan, di samping hutang atau kredit. Di Nagari
Tiku Selatan terdapat tidak kurang dari 20an kelompok arisan dengan jumlah perolehan arisan bisa mencapai jutaan bahkan puluhan juta. Keanggotaan para nelayan dalam kelompok arisan bisa lebih dari satu. Hasil uang yang diperoleh dari hasil arisan ini mereka sertakan lagi dalam kelompok kelompok arisan yang lain, sehingga yang bersangkutan bisa memperoleh modal untuk membuka usaha perdagangan kecil-kecilan (pedagang kelontong), membuat rumah, menyelenggarakan lamaran dan pesta perkawinan, naik haji, dan atau dibelikan perahu/jaring kecil untuk melanggengkan matapencaharian mereka sebagai nelayan. Hal ini, juga berlaku di kalangan para juragan pemilik kapal/perahu dengan jumlah omset arisan yang lebih besar (Rp.10 juta - Rp.50 juta). Oleh karena itu, sejumlah juragan kapal/perahu tidak hanya memiliki lebih dari satu armada kapal/perahu besar yang berharga ratusan juta rupiah, tetapi mereka juga mampu mengembangkan bisnis lain seperti membuka toko, tetapi kebanyakan menginvestasikannya dengan membeli mobil-mobil penumpang (colt diesel) untuk usaha transportasi pengangkutan ikan olahan.

$\begin{array}{ccc}\text { Hutang sebagai salah satu } \\ \text { karakteristik } & \text { perekonomian }\end{array}$
tradisional, dalam banyak hal hampir selalu tidak menguntungkan secara ekonomis bagi si penghutang atau peminjam (kreditur). Hal ini, tampaknya kurang disadari oleh masyarakat nelayan tradisional di Nagari Tiku Selatan, sehingga sampai kini pun masyarakat setempat masih banyak terlibat dalam praktik hutang dan kredit, selain menggabungkan diri ke dalam kelompok-kelompok arisan yang menjamur di Nagari Tiku Selatan, sebagaimana telah dibicarakan di atas. Hutang atau kredit (ngredit) yang dilakukan oleh masyarakat nelayan setempat, umumnya tidak dalam kerangka hubungan kerja antara nelayan dan juragan. Hutang atau permintaan kredit biasanya dilakukan oleh para nelayan kepada orang-orang kaya tetangga-tetangga mereka sendiri yang sama sekali tidak memiliki hubungan kerja dengan dirinya, akan tetapi, pada umumnya mereka lebih sering meminjam uang kepada kepala-kepala arisan yang banyak memegang uang-uang titipan 
para anggotanya.

\section{Strategi Pengembangan Kelembaga an Sosial Nelayan}

$\mathrm{D}$ alam rangka pemberdayaan masyara kat kelompok nelayan yang ada di Nagari Tiku Selatan untuk mencapai tujuan maka disusun suatu strategi kebijakan dengan harapan akan didapat suatu pemecahan dalam memberdayakan masyarakat nelayan secara maksimal sehingga berdampak pada menurunnya tingkat desa tertinggal dan menuju kemandirian desa secara ekonomi, di wilayah masyarakat nelayan Nagari Tiku Selatan. Terdapat strategi pengembangan kelembagaan kelompok nelayan yang sangat diharapkan untuk menunjang berdayanya lembaga kelompok nelayan yang ada di Nagari Tiku Selatan.

Untuk mencapai nelayan yang berkualitas, maka menjadi suatu keharusan bahwa kelompok nelayan yang ada harus memiliki gerak atau kekuatan yang dapat menentukan dan mempengaruhi perilaku kelompok dan anggota-anggotanya dalam mencapai tujuan-tujuan secara efektif. Dengan kata lain kelompok tersebut harus berfungsi efektif untuk kepentingan para anggotanya. Salah satu faktor penting untuk terwujudnya kelompok nelayan yang efektif adalah berjalannya kepemimpinan dari ketua kelompok nelayan tersebut. Ketua kelompok dapat dipandang sebagai agen primer untuk efektifnya kelompok, karena peran strategisnya dalam mempengaruhi atau menggerakkan anggota-anggota di kelompoknya untuk mencapai tujuan-tujuan kelompok maupun dari anggota-anggotanya.

Ketua kelompok dengan kepemim pinannya yang tergolong baik atau sangat tinggi tersebut akan memberikan peluang yang sangat besar untuk tercapainya keefektifan di kelompok yang dipimpinnya tersebut. Hal ini dimungkinkan karena ketua kelompok yang kepemimpinan baik atau sangat tinggi memiliki kemampuan yang lebih baik atau lebih tinggi di dalam mempengaruhi anggota lainnya. Hal ini termasuk di dalam menyusun struktur atau pengubahan stuktur yang diselaraskan dengan persepsi dan harapan para anggota untuk mencapai keberhasilan usaha kelompok. Pada kelompok yang kepemimpinannya tergolong baik atau sangat tinggi, keberhasilan kelompok di dalam mencapai tujuannya, keadaan moral anggota kelompok dan tingkat kepuasan dari para anggota terbukti lebih baik atau lebih tinggi dibanding dengan kelompok yang kepemimpinannya belum berjalan dengan baik.

Pembinaan dari berbagai instansi hendaknya bersifat terintegrasi, lebih mengedepankan kepentingan nelayan, dalam arti nelayan bukan dijadikan obyek untuk kepentingan institusional yang sekedar administrasi keproyekan. Adanya koordinasi yang efektif antar kelembagaan pemerintah dalam pembinaan masyarakat nelayan dapat meningkatkan efisiensi dan produktivitas perikanan melalui kemitraan usaha. Peran pemerintah lebih ditonjolkan pada aspek mediasi, konsultasi, dan fasilitasi dalam membangun kemitraan pengolahan produksi ikan yang berdaya saing.

\section{G. Kesimpulan}

$\mathrm{K}$ elembagaan sosial atau pranata sosial mampu memberikan kekuatan yang positif bagi nelayan dalam kehidupan keseharian mereka. Kelemba gaan sosial perikanan dalam hal ini mampu memberikan jawaban atas permasalahan di atas. Penguatan kelompok sosial nelayan melalui kelembagaan sosial merupakan suatu kebutuhan yang sangat mendesak dan mutlak diperlukan oleh nelayan, agar mereka dapat bersaing dalam melaksana kan kegiatan usaha perikanan dan dapat meningkatkan kesejahteraan hidupnya.

Pengembangan masyarakat nelayan melalui kelembagaan sosial perikanan merupakan suatu upaya pemberdayaan terencana yang dilakukan secara sadar dan sungguh-sungguh melalui usaha bersama nelayan untuk memperbaiki keragaman sistem perekonomian masyarakat pedesaan. Arah pemberdayaan nelayan akan disesuaikan dengan kesepakatan yang telah dirumuskan bersama. Dengan partisipasi yang tinggi terhadap kelembagaan nelayan, diharapkan rasa ikut memiliki dari masyarakat atas semua kegiatan yang dilaksanakan akan juga tinggi. Keberhasilan penerapan suatu kelembagaan sosial nelayan tidak semata- 
mata diukur dengan nilai tambah ekonomi, namun harus mempertimbangkan peran dan fungsi nilai-nilai sosio-kultural secara utuh. Nilai sosio-kultural mencerminkan keberagaman adat dan budaya bangsa Indonesia yang menjunjung tinggi kebhinekaan dalam kerangka Negara Kesatuan Republik Indonesia. Pengembangan kelembagaan sosial nelayan ke depan hendaknya mencerminkan jati diri bangsa Indonesia dengan menggunakan kaca mata modernisasi sebagai salah satu alat pembenaran dan bukan semata-mata mengedepankan kelembagaan yang tidak mencerminkan kearifan lokal masyarakat.
Kelembagaan tradisional yang masih hidup di Nagari Tiku Selatan adalah kelompok sosial pengajian, arisan ibu-ibu dan yasinan, masih berjalan dengan baik. Partisipasi rumah tangga terhadap kelompok sosial juga sangat baik. Hampir seluruh ibu-ibu terlibat dalam kegiatan rutin kelompok tersebut. Pengajian dan yasinan dilaksanakan setiap minggu secara bergilir dari rumah ke rumah. Sedangkan arisan dilaksanakan setiap dua minggu. Strategi sosial dilakukan dengan jalan memanfaatkan ikatan-ikatan sosial yang ada di perdesaan baik berupa lembaga kesejahteraan lokal, hubungan produksi hingga jejaring sosial berbasis kekerabatan atau pertemanan.

\section{Daftar Pustaka}

Acheson, James M. (1981). "Anthropology of Fishing". Annual Review Anthropology Inc. Vol. 10. $\mathrm{P} 275-316$

Astuty, Ernany Dwi dkk. 2006. Restrukturisasi Institusi Ekonomi. Jakarta, Pusat Penelitian Ekonomi-LIPI.

Arief, A. Adri. "Pemberdayaan Nelayan Melalui Pendekatan Kelembagaan Lokal (Studi Kasus Desa Pajukukang, Kecamatan Maros Utara, Kabupaten Maros" dalam http://id.scribd.com/doc/13134563/Dr-Andi-Adri-Arief-kelembagaan-masyarakatpesisir, diakses tanggal 25 Januari 2013, jam 22.50.

Boedhisantoso, S.(1999). Komunitas Lokal di Kawasan Pesisir dan Pemberdayaannya. Makalah Lokakarya Pembangunan Pranata Sosial Komunitas pesisir. Depok 30 Mei - 1 juni 1999

Bungin, Burhan, 2004, Metodologi Penelitian Kualitatif:Aktualisasi Metodologis ke Arah Ragam Varian Kontemporer, Jakarta: PT. RajaGrafindo Persada.

Cohen, A. P. 1985. The Symbolic Construction of Community London: Tavistock

Danim, Sudarwan, 2002, Menjadi Peneliti Kualitatif, Bandung: Pustaka Setia.

Frazer, E. 1999. The Problem of Communitarian Politics: Unity and Conflict. Oxford: Oxford University Press.

Ginkel, Rob van. 2007. Coastal Cultures: An Anthropology of Fishing and Whaling Traditions. Apeldoorn: Het Spinhuis Publishers

Keesing, Roger M. 1989. Antropologi Budaya: Suatu Perspektif Kontemporer. Jakarta: Erlangga

Kharisma Nugroho dan Kwan Men Yon, 2011. Pengurangan Resiko Bencana Berbasis Komunitas di Indonesia dalam http://www.mpbi.org/files/workshops/ 20111205Kharisma-N-Kwan-MY PRBBK-di-Indonesia Nov-2011.pdf

Kluckhon, Clyde 1984. "Cermin bagi Manusia", dalam Parsudi Suparlan (Ed.). Manusia, Kebudayaan, dan Lingkungannya. Jakarta: Rajawali Pers.

Koentjaraningrat. 1987. Kebudayaan Mentalitas dan Pembangunan. Jakarta: PT Gramedia Kusnadi. 2000. Nelayan: Strategi Adaptasi dan Jaringan Sosial. Bandung: Humaniora Utama Press.

2001. Pangamba' Kaum Perempuan Fenomenal: Pelopor dan Penggerak Perekonomian Masyarakat Nelayan. Bandung: Humaniora Utama Press. 2003. Akar Kemiskinan Nelayan. Yogyakarta: LKiS.

2009. Keberdayaan Nelayan dan Dinamika Ekonomi Pesisir. Yogyakarta: Ar- Ruzz Media. 
.2010. "Kebudayaan Masyarakat Nelayan" dalam Makalah ini disampaikan dalam kegiatan JELAJAH BUDAYA TAHUN 2010, dengan tema "Ekspresi Budaya Masyarakat Nelayan di Pantai Utara Jawa", yang Diselenggarakan oleh Balai Pelestarian Sejarah dan Nilai Tradisional, Kementeian Kebudayaan dan Pariwisata, di Yogyakarta, tanggal 12-15 Juli 2010.

Lassa dan dkk. 2009. Pengelolaan Risiko Bencana Berbasis Komunitas (PRBBK). Jakarta: Penerbit PT Gramedia Widiasarana Indonesia

Masyhuri. 1995. Pasang Surut Usaha Perikanan Laut, Tinjauan Sosial Ekonomi Kenelayanan di Jawa dan Madura 1850-1940. Vrije Universiteit Academich Proefschrijtt.

Moleong, Lexy, 2001, Metode Penelitian Kualitatif, Bandung: PT.Remaja Rosda Karya

Neuman, W. Lawrence, 2006, Social Research Methods: Qualitative and Quantitative Approaches $6^{\text {th }}$ Edition, US: Pearson International Edition

Pasaribu LO. 2007. "Kelembagaan Pengelolaan pada Masyarakat Dayak Kenyah di Pampang Kecamatan Samarinda Utara, Kalimantan Timur" [skripsi]. Bogor: Fakultas Kehutanan, Institut Pertanian Bogor

Pranadji T. 2003. Menuju Transformasi Kelembagaan dalam Pembangunan Pertanian dan Pedesaan. Jakarta: Pusat Penelitian dan Pengembangan Sosial Ekonomi Pertanian.

Rudito, Bambang dan Melia Famiola, 2008, Social Mapping (Metode Pemetaan Sosial): Teknik Memahami Suatu Masyarakat atau Komuniti, Bandung: Rekayasa Sains.

Sallatang, Mohammad Arifin. 1982. "Pinggawa Sawi Suatu Studi Sosiologi Kelompok Kecil". Disertasi. Makassar: Universitas Hasanuddin.

Soekanto S. 2002. Sosiologi Suatu Pengantar. Jakarta: PT. Raja Grafindo Persada

Soemardjan S, Soelaeman S. 1974. Setangkai Bunga Sosiologi. Jakarta: Fakultas Ekonomi. Universitas Indonesia.

Zamzami, Lucky. (2009). "Sistem Pengetahuan Lokal Nelayan Terhadap Teknologi Penangkapan Ikan pada Masyarakat Pasar Laban, Kecamatan Bungus Teluk Kabung, Kota Padang" dalam Jurnal FENOMENA Volume 07, Nomor 02, September 2009

Zamzami, Lucky. (2009). "Studi Kualitatif Dampak Perubahan Sosial terhadap Amalan Merantau di Kalangan Nelayan." Satu Kajian Kes di Kelurahan Purus, Kota Padang: UKM Malaysia: Tesis yang tidak dipublikasikan.

Zamzami, Lucky. 2010. Pemberdayaan Ekonomi Masyarakat Pesisir di Nagari Ampiang Perak, Sumatera Barat dalam Jurnal MIMBAR MIMBAR, Vol. XXVII, No. 1 (Juni 2011): 113-125 Terakreditasi' SK Dikti No. 64a/DIKTI/Kep/2010.

\section{Internet}

http://korantransaksi.com. Gubernur Sumbar Berikan Dana PUMP Untuk 21 Kelompok Nelayan Di Agam.

http://www.sumbarprov.go.id/index.php. Gubernur Sumbar Dukung Rencana Pembangunan Dermaga Tiku 